\title{
Analisa Perancangan Sistem Informasi Akuntansi Event Organizer Dengan Aplikasi Accurate Versi 5 (Studi Kasus: PT. Inti Nuansa Ciptavisi)
}

\author{
Mari Rahmawati ${ }^{1}$, Annisa Martriani ${ }^{2}$ \\ ${ }^{1}$ Program Studi Sistem Informasi Akuntansi \\ Universitas Bina Sarana Informatika \\ J1. Kamal Raya No.18, Rigroad Barat, Cengkareng, Jakarta Barat \\ e-mail: mari.mrw@bsi.ac.id \\ ${ }^{2}$ Universitas Bina Sarana Informatika \\ Jl. Kamal Raya No.18, Ringroad Barat, Cengkareng, Jakarta Barat \\ e-mail: myanissa15@gmail.com
}

(Rahmawati \& Martriani, 2019)

Rahmawati, M., \& Martriani, A. (2019). Analisa Perancangan Sistem Informasi Akuntansi Event Organizer Dengan Aplikasi Accurate Versi 5 (Studi Kasus: PT. Inti Nuansa Ciptavisi). Moneter, 6(2), 1-10.

\begin{abstract}
The development of science and technology is now able to influence human life, especially for companies. To get a better and optimal work result, companies use this technology by developing an existing system that is to make manual system changes into a modern system. PT. Inti Nuansa Ciptavisi (INC Production) is a service company engaged in the event organizer. In making financial reports still use manual methods that require accuracy and a very long time, so the transactions carried out often get problems or errors that cause transactions not on time or late. Accurate version 5 is an accounting application that provides the best solution to solve existing problems, this application can help the process of accounting work to be faster and more precise.
\end{abstract}

Keywords: Accounting Information System, Financial Report, Accurate version 5

\section{PENDAHULUAN}

Akuntansi memerlukan database yang confidential karena seluruh transaksi yang ada rata-rata berkaitan dengan keuangan sebuah perusahaan atau badan perseorangan. Pengelolaan akuntansi secara manual memiliki lebih banyak resiko dibandingkan dengan menggunakan sistem yang terkomputerisasi. Misal, dalam hal yang paling sederhana yaitu penginputan jurnal, seringkali terjadi penggandaan, atau dua kali input dengan nomor atau kode voucher yang sama dengan tansaksi yang berbeda.

Hal ini dapat berakibat pada tidak balance-nya buku besar dan laporan keuangan yang dibuat. Kemungkinan lain adalah sudah membayar hutang ke vendor, tetapi karena pencatatanya masih manual, suatu saat datang surat tagihan pembayaran dari vendor yang menyatakan belum membayar atas sejumlah tagihan, dan tidak dapat mencarinya dengan cepat, informasi waktu pembayaran, dengan apa harus dibayar, misal dengan giro atau cek, nomor berapa gironya, dan informasi lainnya.

Atas dasar contoh diatas, maka dapat disimpulkan bahwa bidang akuntansi pun sangat membutuhkan sistem terkomputerisasi. Didukung dengan pengetahuan ilmu teknologi, maka bidang akuntansi dan teknologi informasi dapat menciptakan berbagai macam software aplikasi akuntansi salah satunya adalah Accurate Versi 5 Accounting.

Sebuah organisasi dengan tujuan menghasilkan keuntungan dengan cara menjual jasa kepada para pelangganya. Tujuan operasional dari sebagian besar perusahaan adalah untuk memaksimalkan profit. (Hery, 2012)

Laporan keuangan disiapkan untuk memberikan informasi yang berguna bagi para pemakai laporan (users), terutama sebagai dasar pertimbangan dalam proses pengambilan keputusan. (Hery, 2012)

\section{METODOLOGI PENELITIAN}

\section{Akuntansi}

Menurut A Statement of Basic Accounting Theory (ASOBAT) dalam (Harahap S. , 2015), Akuntansi didefinisikan sebagai proses mengidentifikasi, mengukur, dan menyampaikan informasi ekonomi sebagai bahan informasi dalam hal mempertimbangkan berbagai alternatif dalam mengambil kesimpulan oleh para pemakainya.

Sedangkan menurut American Institute of Certified Public Accountants: 
(AICPA) dalam (Hery, 2017), “Akuntansi adalah seni pencatatan, pengklarifikasian, dan pengikhtisaran transaksi dan peristiwa keuangan dengan cara tertentu dalam ukuran moneter, termasuk penafsiran atas hasil-hasilnya".

\section{Sistem Informasi Akuntansi}

Menurut (Andi, 2017)menyatakan, "Sistem Informasi Akuntansi (SIA) merupakan sistem yang mengumpulkan, mencatat, menyimpan, dan memproses data sehingga menghasilkan informasi bagi para pengambil keputusan". a. User yang menggunakan sistem.

b. Prosedur dan intruksi yang digunakan untuk mengumpulkan, memproses, dan menyimpan data.

c. Data mengenai organisasi dan aktifitas bisnisnya.

d. Software yang digunakan untuk memproses data.

e. Infrastruktur teknologi informasi, yang terdiri dari komputer, peripheral device, dan perangkat jaringan.

f. Pengendalian internal untuk menjaga kemanan data SIA.

SIA terdiri dari enam komponen, yaitu:

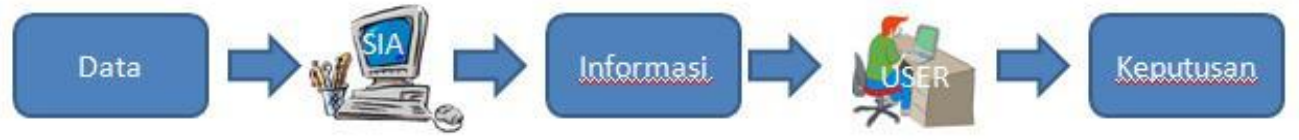

Sumber : (Andi, 2017)

Gambar 1. Peraga Sistem Informasi Akuntansi

\section{Tool Aplikasi (Accurate Versi 5)}

Tool aplikasi yang digunakan adalah program akuntansi Accurate 5.

Accurate dalam jurnal (Setiawan, 2015) "adalah sebuah aplikasi akuntansi yang dikembangkan oleh PT. Cipta Piranti Sejahtera (CPSSOFT), yang berpusat di Jakarta. Pertama kali diluncurkan pada November 1999, dengan versi 1.0, aplikasi ini terus dikembangkan dan disesuaikan dengan perkmbangan aman serta peraturan IFRS (International Financial Reporting Standards). Genap 16 tahun sejak pertama kali peluncurannya, Accurate telah mencapai versi 4.0. Aplikasi Accurate sendiri dibagi menjadi 3 varian yakni Standart, Deluxe, dan Enterprise Version yang perbedaan utamanya terletak pada modul yang tersedia"

Menurut Sulistiawan dalam jurnal (Rahmawati, 2015) "Program Accurate digunakan karena sangat ekonomis dan berdayaguna jika diaplikasikan dalam suatu badan usaha, dan jauh lebih ekonomis jika dibandingkan dengan software akuntansi tailor made, dan lebih berdayaguna lagi jika dibandingkan software akuntansi impor, dengan tersedianya menu berbahasa Indonesia, Accurate sangat cocok untuk perusahaan di Indonesia".

Beberapa keunggulan Accurate versi 5:

a. Menggunakan tipe database clien/server.

b. Multi User dengan tingkat kewenangan yaitu Create, Edit, dan Report.

c. ACCURATE sudah terbukti handal dan sesuai untuk perusahaan di Indonesia, dikembangkan sesuai dengan PSAK (Pernyataan Standard Akuntansi Keuangan Indonesia). d. READY TO USE Install dan langsung dapat diaplikasikan, Form dapat disesuaikan dengan kebutuhan perusahaan, seperti purchase order, invoice, delivery order. dan lain sebagainya.

e. Kemudahan modifikasi bentuk laporan.

f. Perhitungan pajak yang telah disesuaikan dengan Ketentuan Umum Perpajakan (KUP).

g. Fasilitas Job Costing yaitu mengelompokan barang dalam satu kelompok barang baru dengan proses penggabungan dan nilai cost/biaya yang baru.

h. Multi Curency dengan menghitung realisasi \& keuntungan / kerugian yang belum direalisasi.

\section{HASIL DAN PEMBAHASAN}

\section{Tinjauan Perusahaan}

PT. Inti Nuansa Ciptavisi didirikan pada tahun 2006, resmi terdaftar pada Surat Izin Usaha Perdagangan (SIUP) menengah tercatat pada Nomor: 1233/24.1.0/21.74.00.0000/1.824.271/2015, PT. Inti Nuansa Ciptavisi (INC) merupakan perusahaan yang bergerak dibidang jasa event organizer dan artist management.

\section{VISI:}

1. Menjadikan perusahaan yang unggul dan memiliki keunikan dalam kualitas, kreatif, daam penyajian.

2. Menjadikan pilihan yang utama dari para mitra atau klien karna INC mampu menonjolkan keunikan klien.

3. Memperhatikan keseimbangan faktor bisnis dan tanggungjawab sosial atas karya-karya nya.

\section{MISI:}

1. Mengembangakan ide-ide out of the box dalam jasa yang diberikan.

2. Menciptakan nilai tambah.

3. Pelanggan yang ideal. 
4. Tim ideal

\section{Tinjauan Kasus}

a. Penginputan jurnal sering terjadi penggandaan atau dua kali input dengan nomor atau kode voucher yang sama dengan tansaksi yang berbeda. Hal ini dapat berakibat pada tidak balance-nya buku besar dan laporan keuangan yang dibuat.

b. Pencatatan hutang piutang vendor customer. Kita sudah membayar hutang ke vendor, akan tetapi karena pencatatanya masih manual, suatu saat datang surat tagihan pembayaran dari vendor yang menyatakan belum membayar atas sejumlah tagihan, dan tidak dapat mencarinya dengan cepat.

c. Informasi waktu pembayaran, dengan apa pembayaranya, misal dengan giro atau cek, nomor berapa gironya, dan informasi lainnya.

\section{Pemecahan Masalah dengan Aplikasi Accurate} Versi 5.:

\section{A. Setup Awal}

\section{Membuat Database Perusahaan}

Database baru dapat dibuat dengan dua cara yait dibuat di Local (di dalam hard disk PC sendiri) atau diletakkan di dalam PC orang lain atau server (Remote).

a. Membuat Database Baru di Komputer Lokal Sebelum membuat database di komputer lokal, pastikan Firebird dan program ACCURATE di komputer terinstal dengan baik.

Berikut Langkah-langkahnya :

1) Buka program ACCURATE dengan klik tombl Start Programs/All ProgramCPSSoft- ACCURATE V5.

2) Atau klik icon $A C C U R A T E$ yang terdapat pada desktop computer.

3) Pada tampilan Welcome To ACCURATE, klik tombol Create New Company.

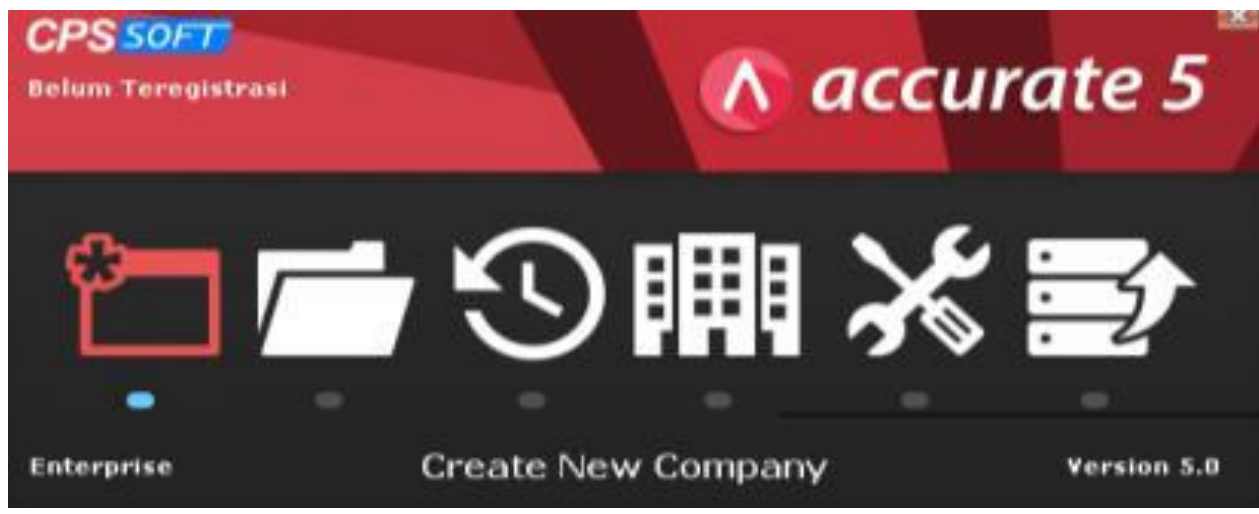

Gambar 2. Form untuk membuat Database Lokal

4) Setelah anda mengklik tombol Creat New Company yang terdapat pada tampilan Welcome ACCURATE, langkah selanjutnya yang dapat anda lakukan adalah meng-klik check box Lokal yang terdapat pada form Create Database. Langkah selanjutnya klik tombol Ellipsis
[...], lalu pilih folder tempat data akan diletakkan, kemudian ketikkan nama file dengan ekstensi *.GDB, lalu klik tombol Create dan $\mathrm{OK}$. Tunggu beberapa saat sampai proses pembuatan database selesai dilakukan. Untuk lebih jelasnya perhatikan gambar berikut ini:
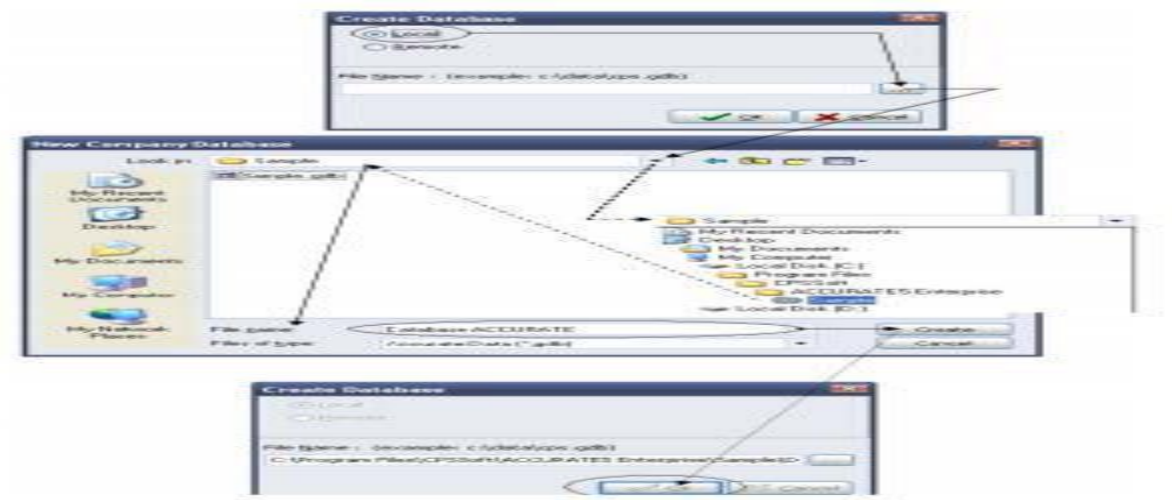

Gambar 3. Membuat Dataase Lokal 
5) Setelah proses pembuatan database ACCURATE selesai dilakukan, langkah selanjutnya Anda dapat Login untuk masuk ke dalam Database tersebut USER ID dan Password = SUPERVISOR (Password tidak mebedakan huruf kecil maupun huruf besar).

a. Membuat Database Baru di Komputer Lain (Remote).

b. Jika Anda menjalankan ACCURATE dari komputer A dan ingin membuat database baru dikomputer B (sebagai komputer server), Anda harus tahu beberapa nomor IP Address atau nama komputer (Computer Name) dari komputer B sebagai komputer server. Sebelum membuat database secara remote pastikan komputer client (komputer A) dan komputer server (komputer B) telah terhubung (terkoneksi) dengan baik. Berikut ini langkah-langkah untuk membuat Database secara remote:

1) Buka program ACCURATE dengan ara Klik tombol start - program/all program - CPSSoft - ACCURATE 5.

2) Atau Klik icon ACCURATE yang terdapat pada desktop komputer anda.

3) Pada tampilan welcome to ACCURATE, Create New Company.

4) Setelah Anda mengklik tombol Create New Company yang terdapat pada tampilan Welcome To ACCURATE, langkah selanjutnya yang dapat dilakukan adalah mengklik check box Remote yang terdapat pada form Create Database, langkah selanjutnya isi:

6)

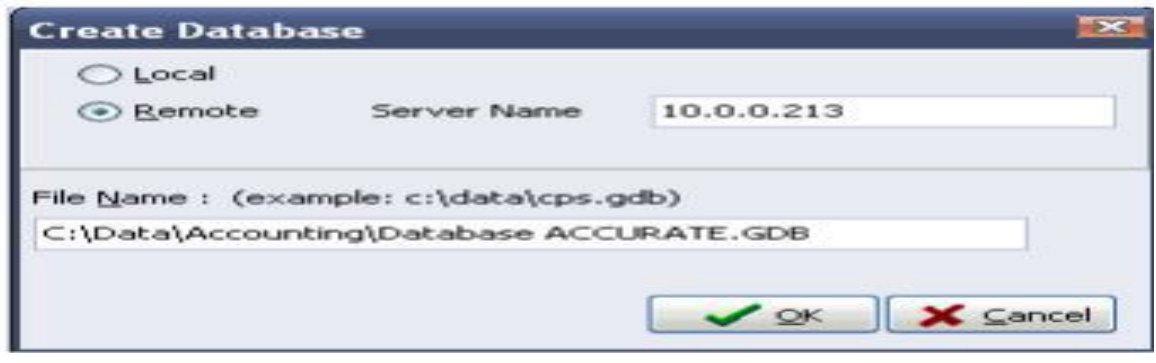

Gambar 4. Form Membuat Database Remote

7) Setelah proses pembuatan database ACCURATE selesai dilakukan, langkah selanjutnya Anda dapat Login untuk masuk ke dalam Database tersebut dengan USER ID dan Password = SUPERVISOR (Password tidak membedakan huruf kecil maupun huruf besar).
Berikut data-data yang perlu disiapkan sebelum memulai transaksi:

1) Saldo Kas dan Bank

2) Buku Piutang

3) Buku Hutang

4) Daftar Barang/Jasa, dan Stok akhir jika ada

Tahap Sebelum Transaksi:

1) Memilih bahasa yang akan digunakan

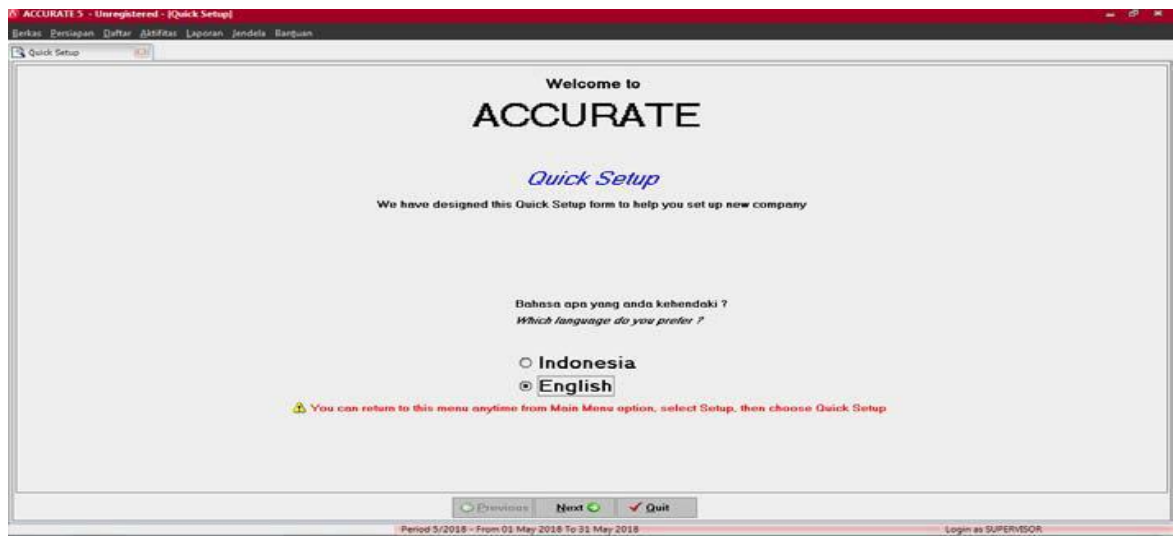

Gambar 5. Form Setup Bahasa 
2) Memilih metode persiapan

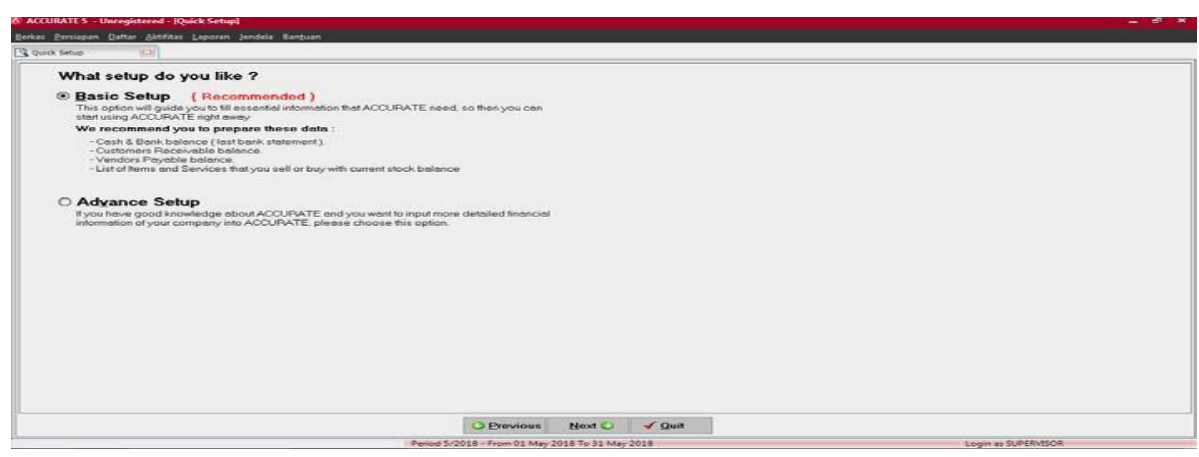

Gambar 6. Form Tipe Persiapan Standar Akuntansi

3) Memasukan data perusahaan dan memilih mata uang yang dipakai

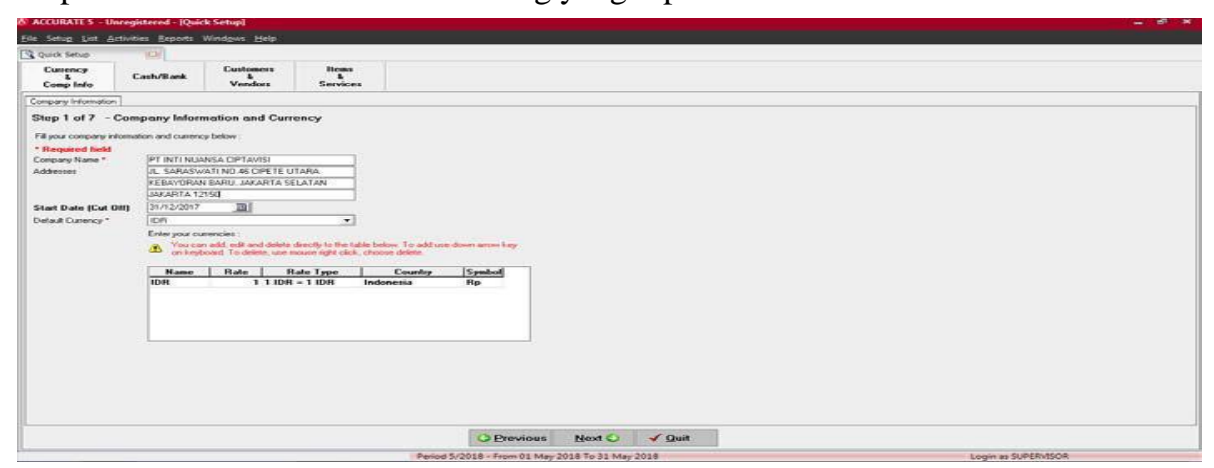

Gambar 7. Form Data Perusahaan

4) Memasukan saldo awal Kas/Bank

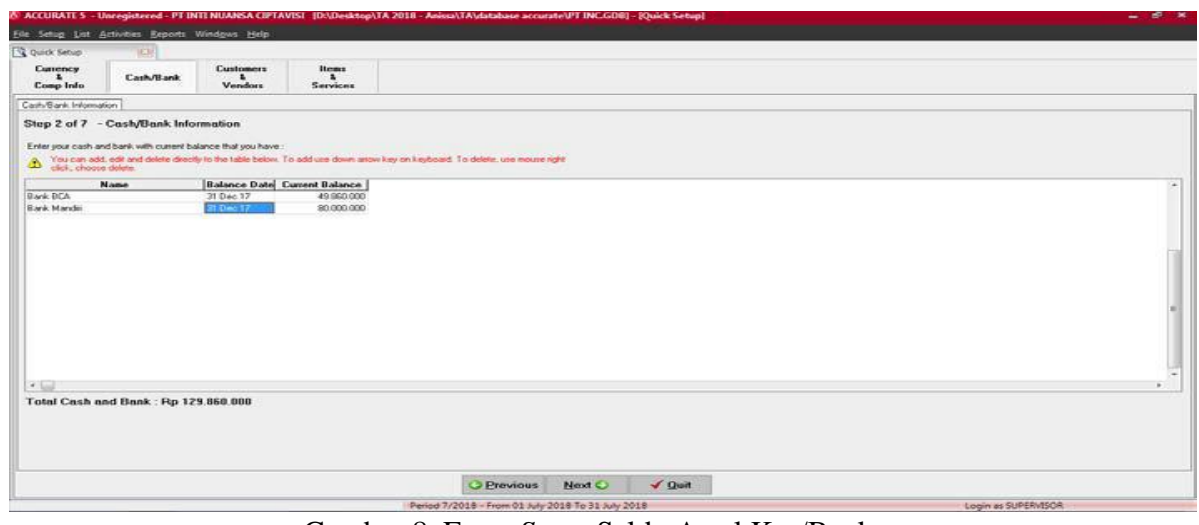

Gambar 8. Form Setup Saldo Awal Kas/Bank

5) Memasukan saldo awal Piutang (Customer)

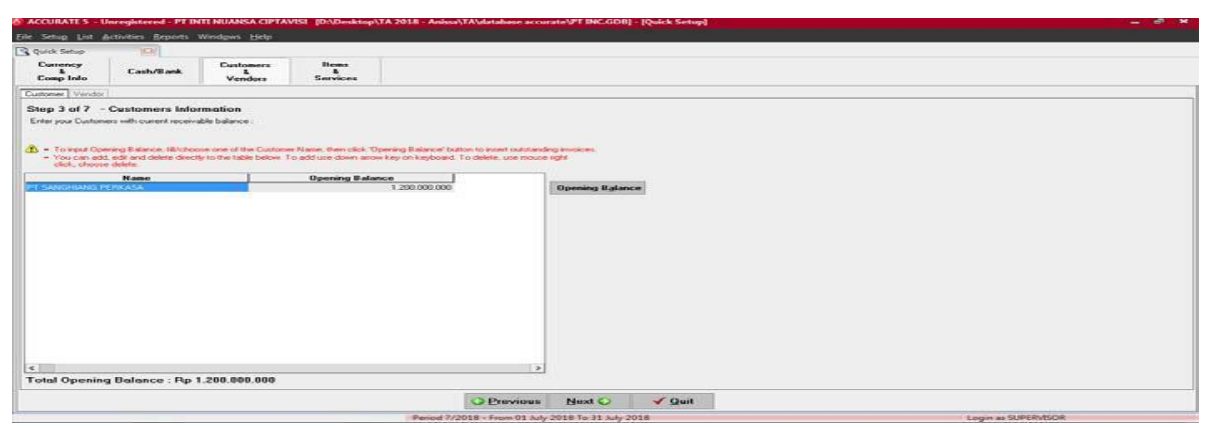

Gambar 9. Form Setup Saldo Awal Piutang 
Analisa Perancangan Sistem Informasi Akuntansi Event Organizer Dengan Aplikasi Accurate Versi 5 (Studi Kasus: PT. Inti Nuansa Ciptavisi)

6) Memasukan saldo awal Hutang (Vendor)

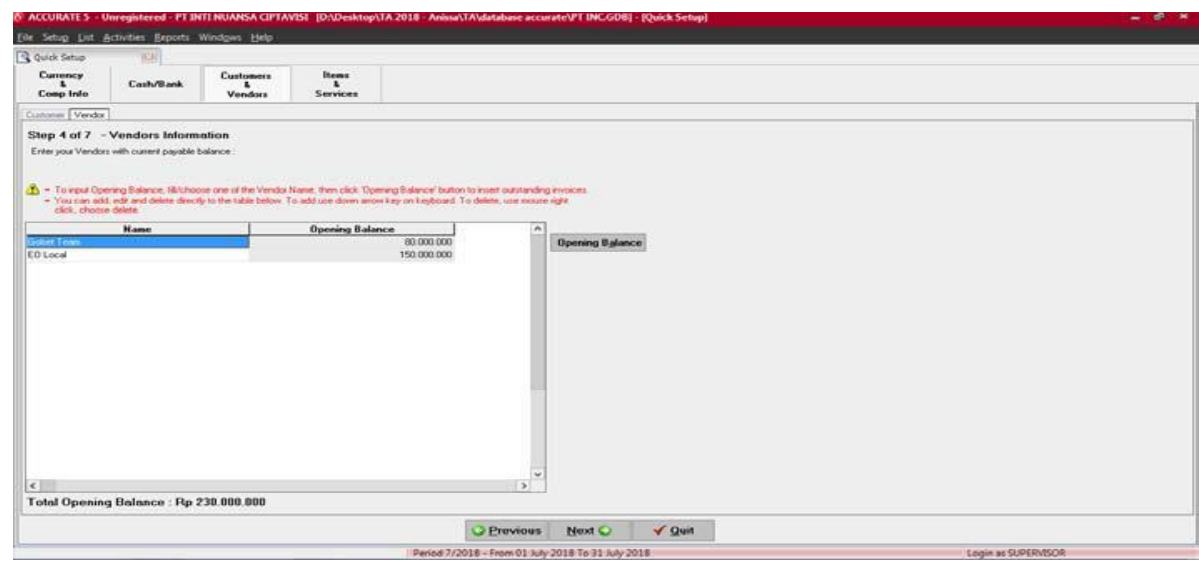

Gambar 10. Form Setup Saldo Awal Hutang

7) Pemberitahuan bahwa persiapan sudah selesai

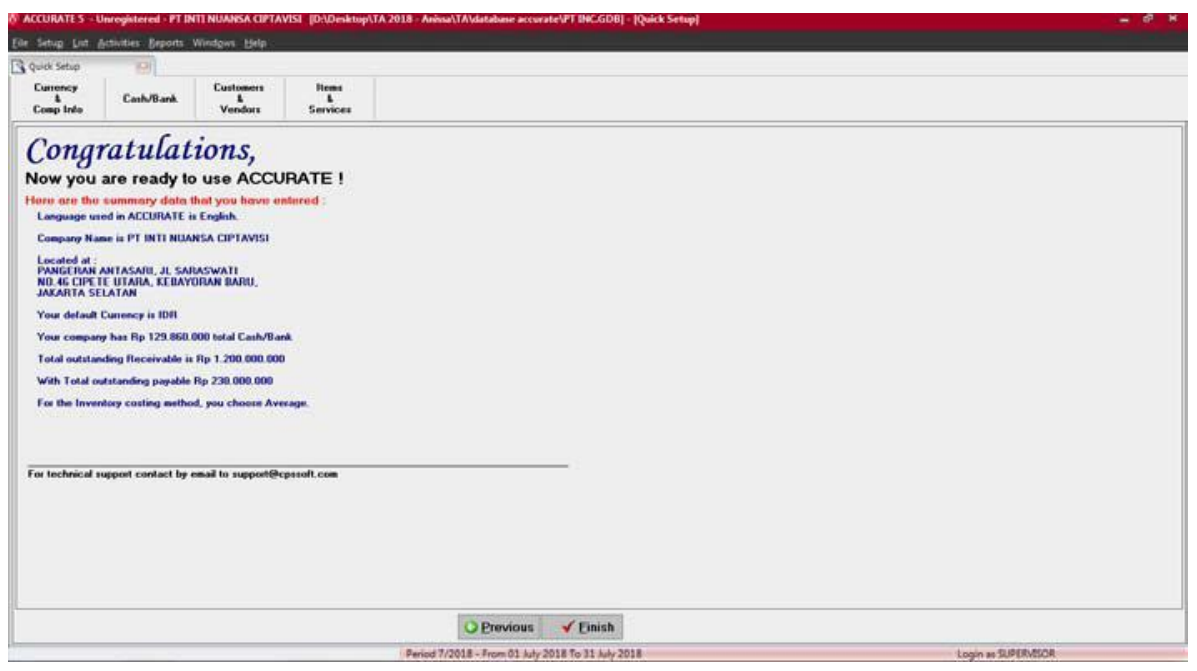

Gambar 11. Form Pemberitahuan

8) Tampilan menu utama pada ACCURATE Versi 5

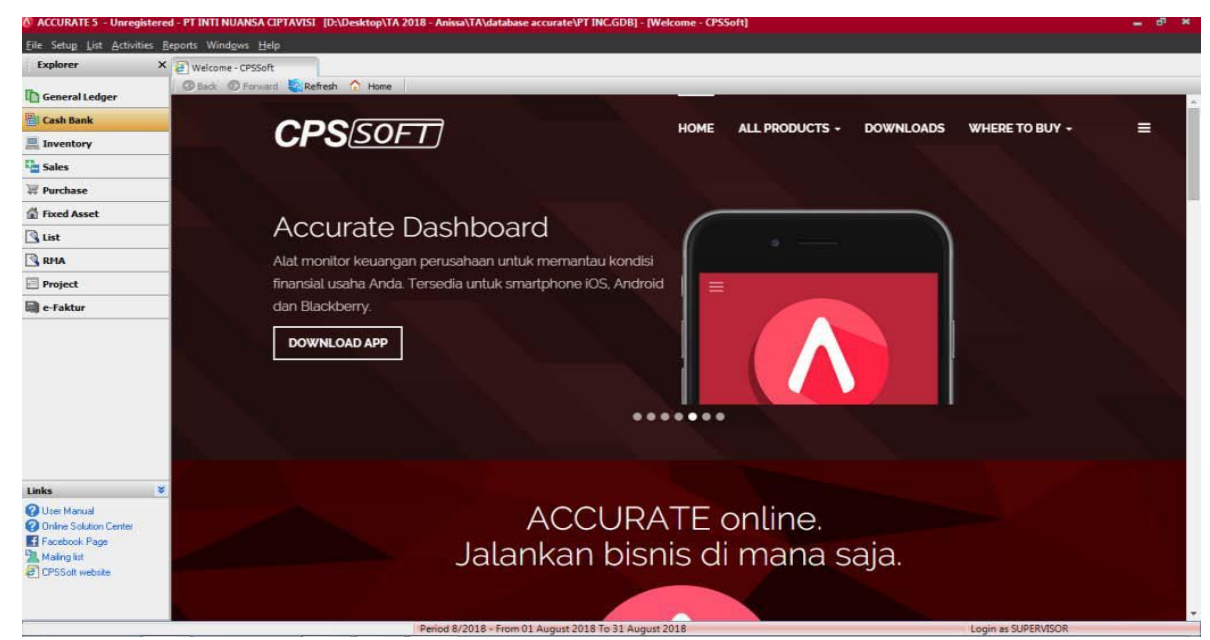

Gambar 12. Tampilan Menu 


\section{B. Laporan}

Berikut beberapa laporan yang disajikan Accurate versi 5.

1. Laporan Laba/Rugi

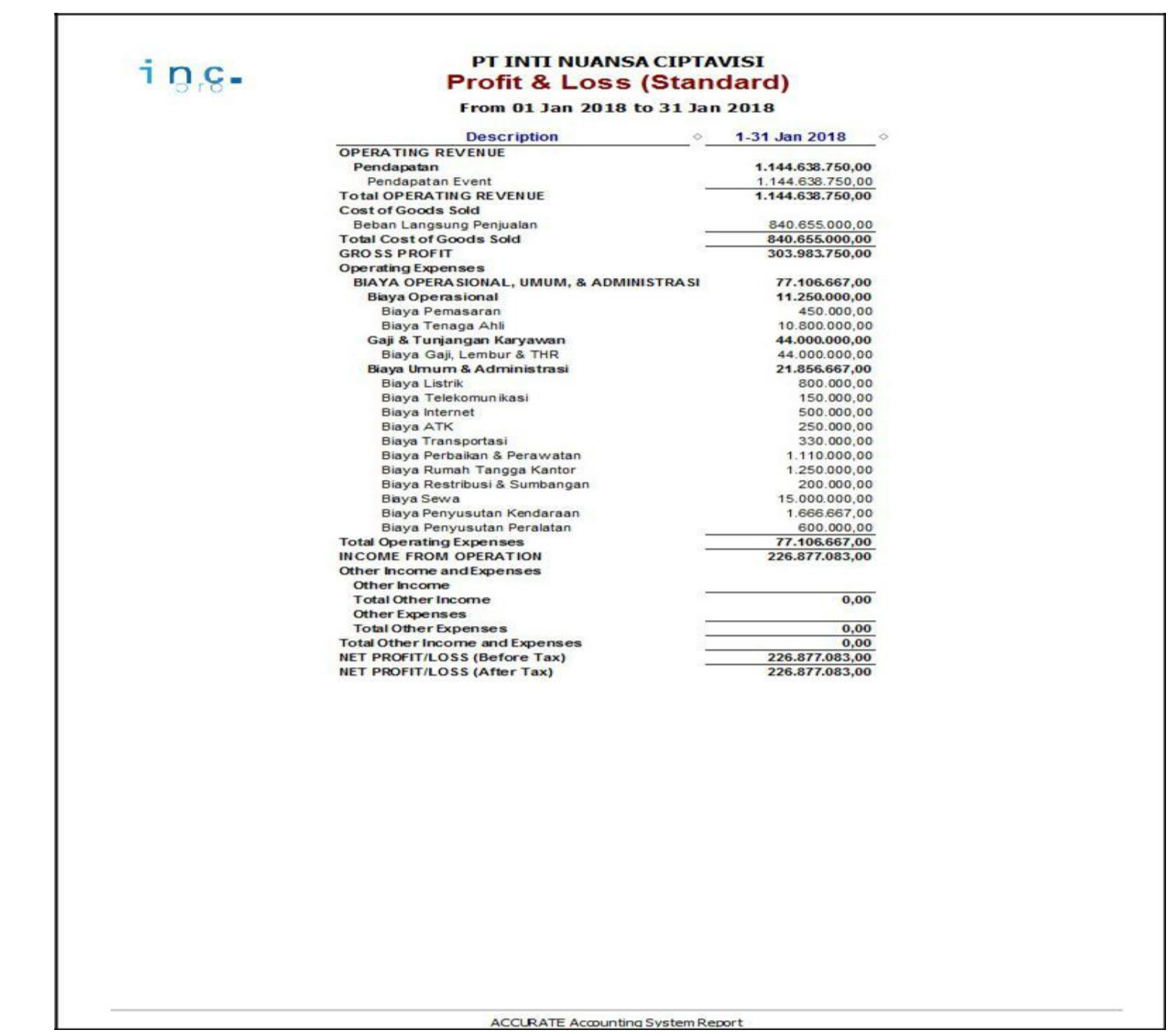

Gambar 13. Laporan Laba/Rugi

2. Laporan Perubahan Modal

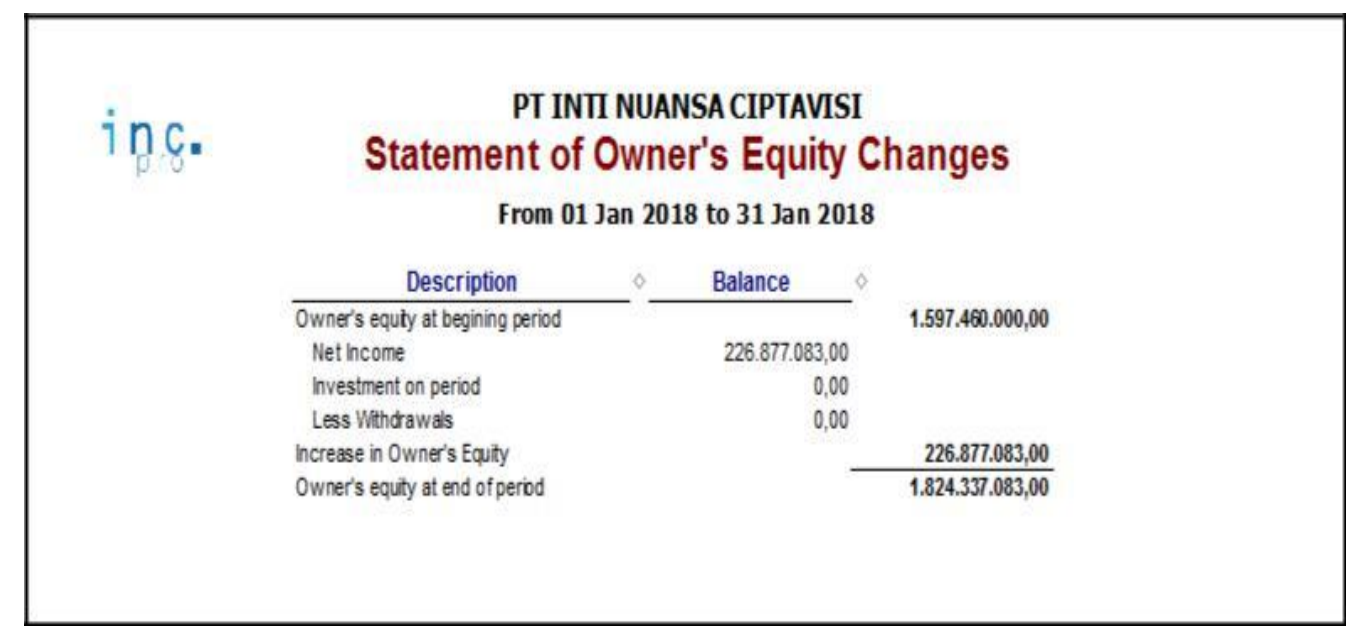

Gambar 14. Laporan Perubahan Modal 
Analisa Perancangan Sistem Informasi Akuntansi Event Organizer Dengan Aplikasi Accurate Versi 5 (Studi Kasus: PT. Inti Nuansa Ciptavisi)

\section{Laporan Posisi Keuangan (Neraca)}

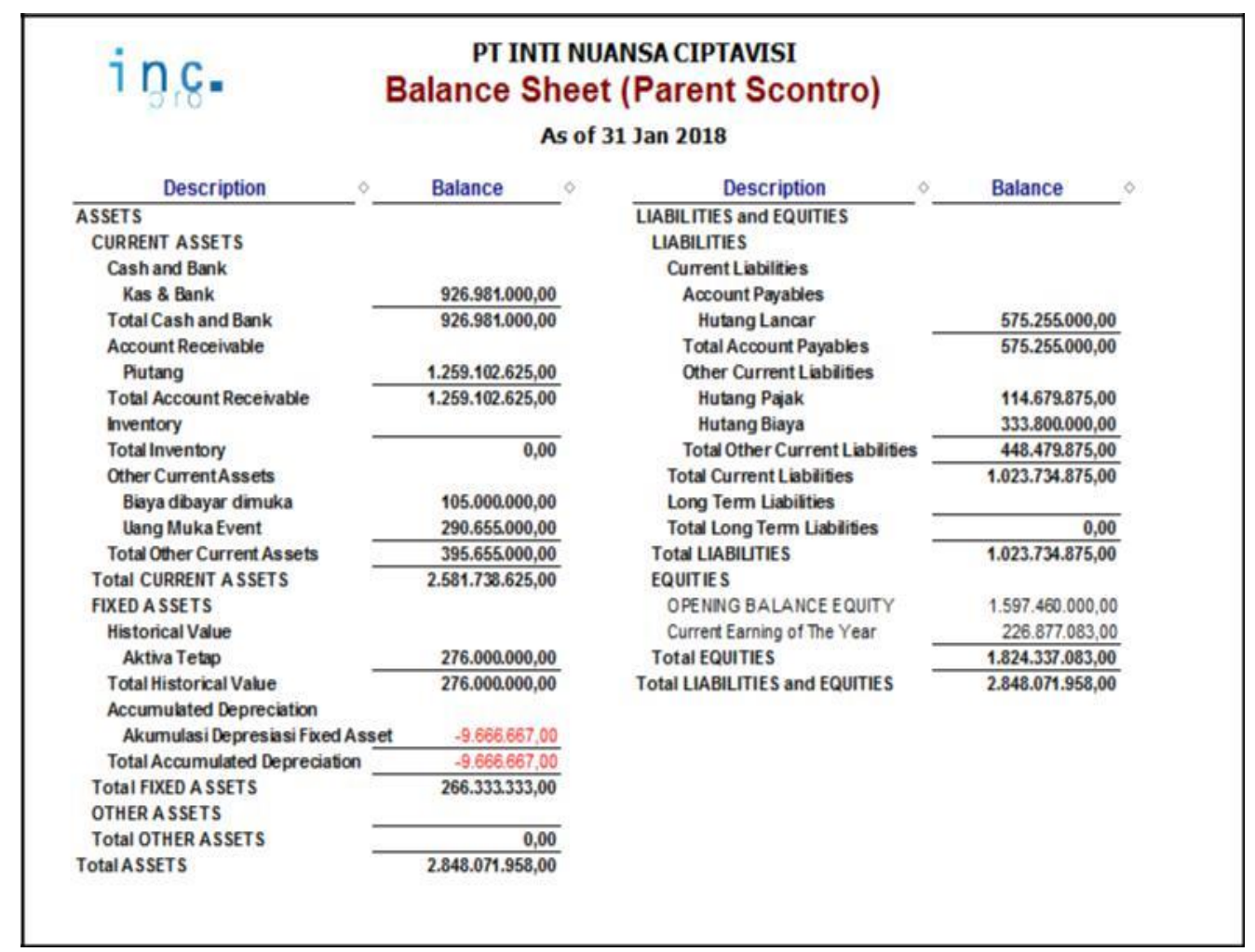

Gambar 15. Laporan Neraca

\section{Analisis Laporan Keuangan}

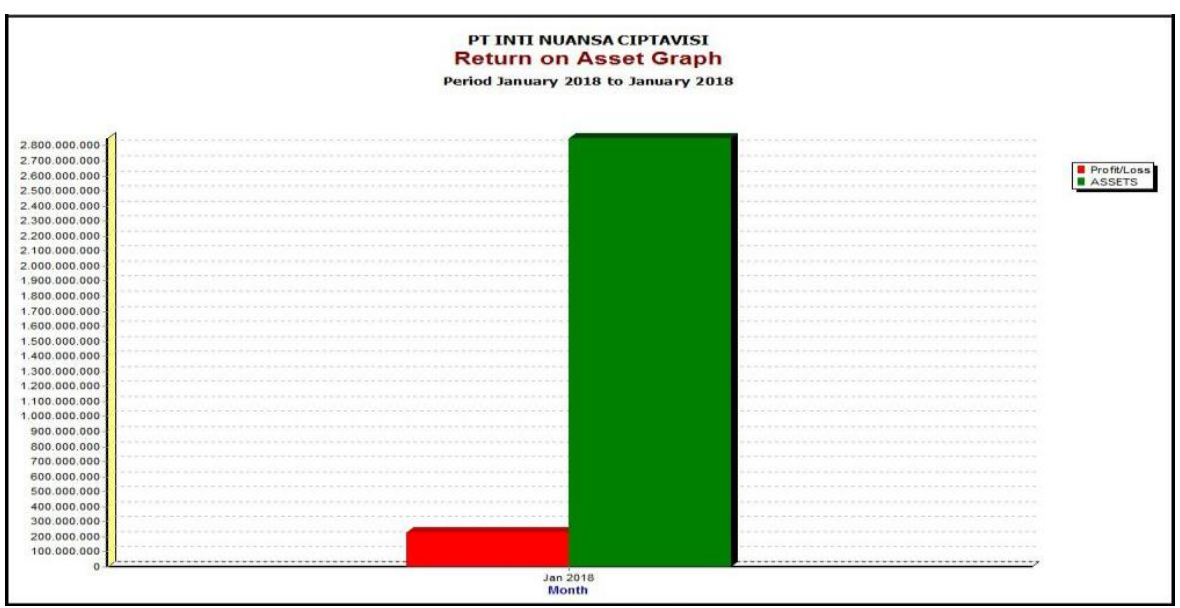

Gambar 16. Rasio Penjualan Bersih Terhadap Aktiva

Rasio Penjualan Bersih Terhadap Aktiva ini adalah untuk mengukur seberapa efektif perusahaan dalam menggunakan aktivanya untuk menghasilkan penjualan. Berdasarkan rasio ini, PT Inti Nuansa Ciptavisi sangat baik dalam memanfaatkan aktiva untuk menghasilkan penjualan. Dengan rata-rata industri yang akan memberikan dasar yang baik untuk interpretasi kinerja keuangan. 


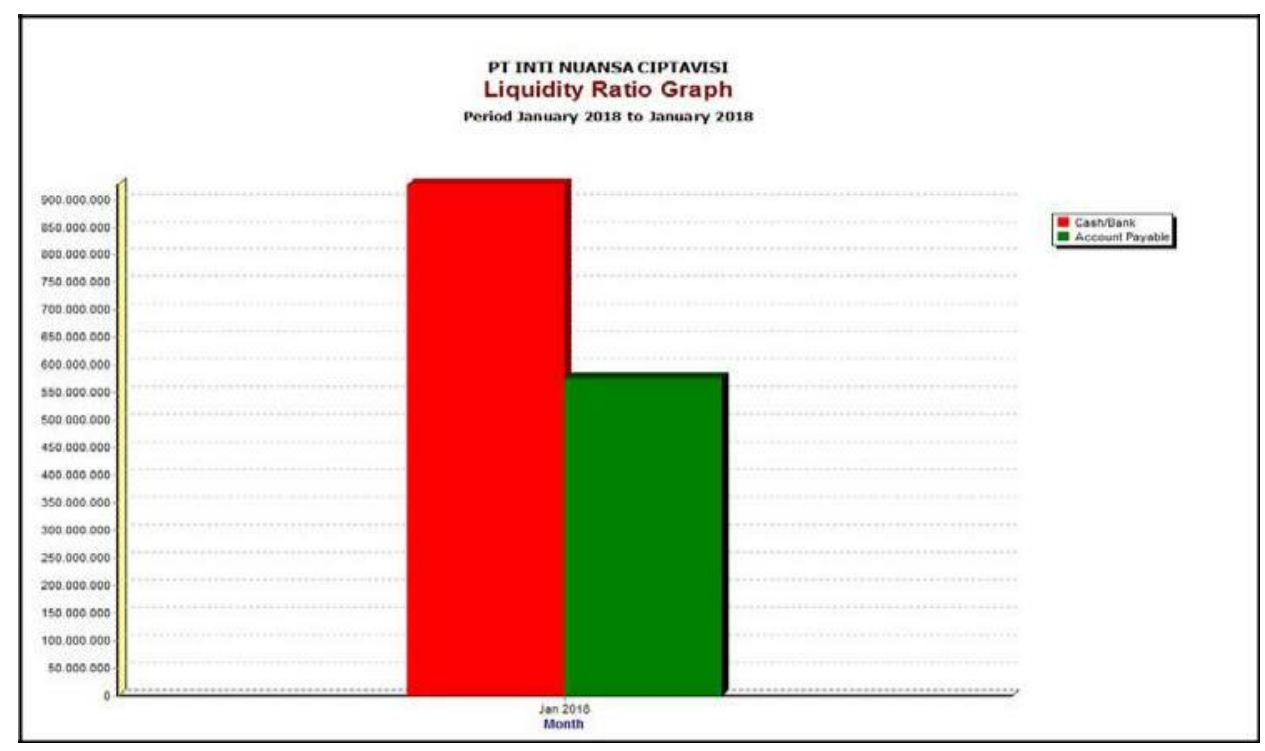

Gambar 17. Rasio Rasio Likuiditas

Rasio likuiditas adalah suatu indikator untuk menggambarkan kemampuan perusahaan dalam memenuhi hutang (kewajiban) jangka pendek. Berdasarkan rasio ini cash rasio PT. Inti Nuansa Ciptavisi sebesar 17\% yang diperoleh dari perbandingan kas (bank) sebesar Rp. 926.891.000 dengan hutang lancar sebesar Rp. 534.679.875. Hal ini berarti setiap Rp. 1 hutang lancar dapat dijamin oleh cash asset sebesar Rp. 1,73.

\section{KESIMPULAN}

Kesimpulan yang diperoleh dari Sistem Informasi Akuntansi dengan penggunaan Aplikasi Accurate dapat:

1. Menjadi alternatif pemecahan masalah dalam penyusunan laporan keuangan.

2. Mengkapi penentuan beban penyusutan dengan beragam metode, serta pembuatan jurnal penyusutannya dilakukan otomatis saat tutup buku bulanan.

3. Meminimalisir kesalahan-kesalahan pencatatan akibat human eror.

4. Dalam hal pencarian data-data keuangan menjadi lebih mudah dan cepat karena dilengkapi dengan pengisian periode tanggal, bulan dan tahun data yang dicari.

Saran yang diperoleh dari Sistem Informasi Akuntansi dengan penggunaan Aplikasi Accurate ini adalah:

1. Diperlukan ketelitian dan kedisiplinan dari pemakai, terutama dalam hal penginputan data, hendaknya sesuai dengan ketentuan yang benar, sehingga secara otomatis keluaran yang dihasilkan akan akurat.
2. Sebaiknya menggunakan software akuntansi yang mudah digunakan, Accurate dapat digunakan meskipun tidak memahami teori akuntansi, namun akan lebih baik jika mempelajari prinsipprinsip dasarnya dan secara tidak langsung dapat meningkatkan pengetahuan para karyawan tentang pengolahan data akuntansi.

3. Sebaiknya diadakan pelatihan kepada karyawan mengenai cara penggunaan software akuntansi agar karyawan dapat menggunakan software akuntansi dengan baik dan maksimal.

4. Dari segi pengamanan data sebaiknya dalam menjalankan program aplikasi akuntansi dibuat back-up data untuk menghindari masalah-masalah yang timbul, seperti kehilangan file dan sebaagainya.

\section{REFERENSI}

Andi. (2017). Sistem Informasi Akuntansi: Esensi dan Aplikasi. (TM Books, Ed.). Yogyakarta.

Harahap, S. S. (2015). Teori Akuntansi. Jakarta: PT. Rajagrafindo Persada.

Hery. (2012). Jakarta: Lembaga Penerbit Fakultas Ekonomi Universitas Indonesia.

Hery. (2017). Teori Akuntansi Pendekatan Konsep dan Analisis. Jakarta: PT. Grasindo.

Rahmawati, M. (2015). Peran Aplikasi Komputer Berbasis Akuntansi Untuk Badan Usaha Dalam Persfektif Sistem Informasi. Perspektif, XIII-No.2, 172-183.

Setiawan, P. 1. (2015). Rancang Bangun Aplikasi Business Intelligence Berbasiskan Arsitektur Aplikasi Akuntansi Accurate. $1(2)$. 
Analisa Perancangan Sistem Informasi Akuntansi Event Organizer Dengan Aplikasi Accurate Versi 5 (Studi Kasus: PT. Inti Nuansa Ciptavisi)

\section{PROFIL PENULIS}

Mari Rahmawati. Menyelesaikan Pendidikan Strata-1 (S1) di STMIK KUWERA-HARVEST, Program Studi: Sistem Informasi, lulus pada tahun 2007 dengan gelar S.Kom. Ia melanjutkan studi Pascasarjana Magister Ilmu Komputer STMIK Nusa Mandiri, Program Studi: Sistem Informasi, Konsentrasi: e-Business, lulus pada tahun 2011 dan memperoleh gelar M.Kom. Penulis bergabung di
Universitas Bina Sarana Informatika sejak tahun 2006-sekarang sebagai dosen tetap dan sudah memiliki Jabatan Fungsional Akademik: Lektor terhitung mulai tanggal 01 Agustus 2018.

E-mail: mari.mrw@bsi.ac.id

Annisa Martriani. Menyelesaikan Pendidikan di Universitas Bina Sarana Informatika, lulus pada tahun 2018 dengan predikat baik. E-mail: myanissa15@gmail.com 